\title{
DIMENSI KEMISKINAN DI WILAYAH PESISIR PADA KABUPATEN INDRAGIRI HULU PROVINSI RIAU
}

\author{
Heffi Christya Rahayu \\ JJ. Sarungu \\ Lukman Hakim \\ AM.Soesilo \\ Fakultas Ekonomi dan Bisnis \\ Universitas Sebelas Maret \\ e-mail: heffirahayu@gmail.com
}

\begin{abstract}
This purpose of this study to analyze the poverty of the region in Indargiri Hilir regency. This study uses panel data. The data used in this study results of Podes survey in 2003, 2006, 2008, 2011 and 2014. The sample used amounted to 465 villages. The results of variables of electric users, TVRI users, hospital distance to the village and access to hospitals have negative and significant value, indicating more and more people use electricity, TVRI and access to hospitals will reduce poverty. While the river variables for crossing between villages and rivers for transportation have positive and insignificant values, indicating that the more rivers for transportation the more poverty will increase.
\end{abstract}

Keywords: poverty, village, district, Indragiri Hilir

\begin{abstract}
ABSTRAK
Tujuan menganalisa kemiskinan di daerah di Kabupaten Indragiri Hilir. Penelitian ini menggunakan data panel. Data yang digunakan dalam penelitian ini hasil survei Podes tahun 2003, 2006, 2008, 2011 dan 2014. Sampel yang digunakan berjumlah 465 desa. Hasil penelitian Variabel pengguna listrik, pengguna TVRI, jarak rumah sakit ke desa dan akses rumah sakit mempunyai nilai negatif dan signifikan, yang menandakan semakin banyak masyarakat menggunakan listrik, TVRI dan akses rumah sakit maka akan mengurangi kemiskinan. Sedangkan variabel sungai untuk melintas antar desa dan sungai untuk transportasi mempunyai nilai positif dan tidak signifikan, yang menandakan bahwa semakin banyak sungai untuk transportasi maka kemiskinan akan semakin meningkat.

Kata kunci: kemiskinan, desa, kabupaten, Indragiri Hilir
\end{abstract}

Permasalahan yang tengah dihadapi oleh dunia adalah kemiskinan. Kemiskinan lahir bersamaan dengan keterbatasan sebagian manusia dalam mencukupi kebutuhannya. Kemiskinan telah ada sejak lama pada hampir semua peradaban manusia. Pada setiap belahan dunia dapat dipastikan adanya golongan konglomerat dan golongan melarat. Dimana golongan yang konglomerat selalu bisa memenuhi kebutuhannya, sedangkan golongan yang melarat hidup dalam keterbatasan materi yang membuatnya semakin terpuruk. 
Beberapa studi yang mengkaji kemiskinan seperti Studi Setboonsarng (2005) di Cina menjelaskan bahwa infrastruktur dapat berkontribusi untuk pengurangan kemiskinan. Studi Oraboune (2008) di Laos menghasilkan hubungan signifikan antara akses sarana kesehatan dengan desa untuk mengurangi biaya transportasi. Studi yang dilakukan oleh Shalini, et.al (2009) di Afrika menjembatani kesenjangan dengan mengeksplorasi dampak infrastruktur transportasi kemiskinan perkotaan (urban poverty). Studi Straub dan Terada (2010) di Asia Timur menjelaskan bahwa infrastruktur (listrik, telekomunikasi, transportasi dan pasokan air) memiliki dampak positif pada ekonomi pertumbuhan.

Sementara itu Chatterjee dan Morshed (2011) di USA menjelaskan bahwa biaya listrik yang rendah akan memberikan masyarakat pedesaan layak untuk produksi, pengolahan, pemasaran dan distribusi. Pada tahun yang sama studi Raihan (2011) di Bangladesh menekan pentingnya infrastruktur secara umum mengurangi kemiskinan. Studi Ahmed (2013) menjelaskan bahwa teknologi untuk penyebaran informasi kekayaan generasi dan penciptaan pengetahuan. Studi yang dilakukan oleh Wang dan Sun (2015) di Cina menghasilkan bahwa investasi di infrastruktur transportasi secara positif mempengaruhi di daerah pedesaan. Penelitian Yanhui dan Baixue (2016) di Cina menjelaskan tentang kemiskinan dan keseluruhan tingkat kemiskinan menunjukkan pola spasial di sekitarnya lebih tinggi.

Beberapa penelitian di Provinsi Riau seperti studi Maryanti (2009) di Provinsi Riau bahwa laju pertumbuhan penduduk yang tinggi berdampak pada PDRB perkapita kabupaten/kota. Diperkirakan dimasa yang akan datang sesuai dengan semakin berkembangnya sebuah daerah, maka akan terjadi peningkatan jumlah penduduk. Hal yang sama studi yang dilakukan oleh Chalid dan Yusuf (2014) menjelaskan bahwa tingkat kemiskinan, tingkat pengangguran, upah minimum kabupaten/kota dan laju pertumbuhan ekonomi berpengaruh terhadap indeks pembangunan manusia (IPM) di Provinsi Riau.

Provinsi Riau adalah provinsi yang kaya, berlimpah ruah akan penghasilannya. Pembangunan di Provinsi Riau belum berjalan dengan baik, hal ini dapat dilihat dengan masih banyaknya rakyat Riau yang belum sejahtera secara keseluruhan. Masalah pembangunan ini juga dikarenakan persebaran penduduk yang tidak merata serta masih adanya kelompok-kelompok yang terasing di pedalaman. Provinsi Riau memiliki banyak potensi SDA dan letak geografis yang strategis, namun belum dapat dimanfaatkan dengan baik. Banyak terjadi kesenjangan dalam pembangunan di Provinsi Riau.

Tabel 1. Jumlah dan Persentase Penduduk Miskin di Provinsi Riau Menurut Daerah, Tahun 2011-2017

\begin{tabular}{|c|c|c|c|c|c|c|c|c|c|}
\hline \multirow{2}{*}{ Tahun } & \multicolumn{3}{|c|}{$\begin{array}{l}\text { Jumlah Penduduk } \\
(000)\end{array}$} & \multicolumn{3}{|c|}{$\begin{array}{l}\text { Jumlah Penduduk Miskin } \\
(000)\end{array}$} & \multicolumn{3}{|c|}{$\begin{array}{c}\text { Persentase Penduduk Miskin } \\
(\%)\end{array}$} \\
\hline & Kota & Desa & $\begin{array}{l}\text { Kotat } \\
\text { Desa }\end{array}$ & Kota & Desa & $\begin{array}{l}\text { Kotat } \\
\text { Desa }\end{array}$ & Kota & Desa & $\begin{array}{l}\text { Kota+ } \\
\text { Desa }\end{array}$ \\
\hline 2011 & $2.226,69$ & $3.462,02$ & $5.688,71$ & 141,84 & 339,96 & 481,81 & 6,37 & 9,82 & 8,47 \\
\hline 2012 & $2.288,80$ & $3.550,27$ & $5.839,07$ & 147,17 & 332,66 & 479,83 & 6,43 & 9,37 & 8,22 \\
\hline 2013 & $2.345,37$ & $3.647,54$ & $5.992,91$ & 144,24 & 618,43 & 462,67 & 6,15 & 8,73 & 7,72 \\
\hline 2014 & $2.411,01$ & $3.743,32$ & $6.154,33$ & 166,36 & 333,52 & 499,89 & 6,90 & 8,91 & 8,12 \\
\hline 2015 & $2.451,40$ & $3.857,72$ & $6.309,12$ & 166,45 & 364,94 & 531,39 & 6,79 & 9,46 & 8,42 \\
\hline 2016 & $2.538,28$ & $3.921,67$ & $6.459,95$ & 162,45 & 352,95 & 515,40 & 6,40 & 9,00 & 7,98 \\
\hline 2017 & $2.630,04$ & $3.986,24$ & $6.616,28$ & 178,58 & 336,03 & 514,62 & 6,79 & 8,43 & 7,78 \\
\hline
\end{tabular}

Sumber: BPS, 2017 (diolah) 
Perkembangan jumlah penduduk di Riau 2011-2017 mengalami fluktuasi jumlah penduduk miskin di kota dan desa terbanyak mencapai 531,39 ribu jiwa di tahun 2015. Tetapi persentase penduduk miskin yang tinggi terjadi pada tahun 2011 sebesar $8,47 \%$. Sementara jumlah penduduk miskin kota dan desa terendah di tahun 2013 sebesar 462,67 ribu jiwa dengan persentase penduduk miskin sebesar $7,72 \%$. Salah satu penyebabnya dana desa yang disalurkan ke daerah banyak yang seharusnya untuk pembangunan desa ternyata digunakan untuk kepentingan pribadi atau kelompok. Sistem dan sumber daya yang belum siap serta kurangnya pengawasan membuat anggaran dana desa banyak tidak tepat sasaran.

Tabel 2. Jumlah Penduduk Miskin Provinsi Riau Tahun 2011-2016

\begin{tabular}{lrrrrrr}
\hline \multirow{2}{*}{ Kabupaten/Kota } & \multicolumn{6}{c}{ Jumlah Penduduk Miskin (000 Jiwa) } \\
\cline { 2 - 7 } & 2011 & 2012 & 2013 & 2014 & \multicolumn{1}{c}{2015} & 2016 \\
\hline 1.Kuantan Singingi & 31,07 & 31,26 & 34,71 & 33,52 & 34,1 & 31,22 \\
2.Indragiri Hulu & 27,51 & 27,68 & 29,60 & 29,4 & 31,63 & 29,73 \\
3.Indragiri Hilir & 52,82 & 53,01 & 54,18 & 52,39 & 56,85 & 56,82 \\
4.Pelalawan & 37,59 & 38,28 & 43,55 & 42,67 & 47,53 & 45,35 \\
5.Siak & 20,83 & 21,04 & 23,21 & 22,54 & 24,81 & 24,86 \\
6.Kampar & 61,20 & 61,75 & 68,58 & 67,61 & 72,22 & 67,68 \\
7.Rokan Hulu & 52,82 & 53,55 & 59,85 & 58,29 & 64,74 & 67,42 \\
8.Bengkalis & 34,96 & 35,25 & 40,11 & 38,82 & 40,44 & 37,49 \\
9.Rokan Hilir & 43,77 & 44,02 & 47,47 & 46,97 & 49,13 & 52,40 \\
10.Kep.Meranti & 65,58 & 63,85 & 64,02 & 61,07 & 61,64 & 56,18 \\
11.Pekanbaru & 32,34 & 32,66 & 32,46 & 32,29 & 33,76 & 32,49 \\
12.Dumai & 13,97 & 14,11 & 13,72 & 13,62 & 14,97 & 13,76 \\
\hline Provinsi Riau & 472,45 & 476,46 & 511,47 & 498,28 & 531,39 & 515,40 \\
\hline Sumber: BPS 2017 & & & & & &
\end{tabular}

Jumlah penduduk miskin Provinsi Riau dari tahun ke tahun mengalami kenaikan. Jumlah penduduk miskin di Kabupaten Indragiri Hilir dari tahun ke tahun mengalami peningkatan. Tahun 2016 penduduk miskin di Kabupaten Indragiri Hilir mencapai 56,82 jiwa. Sementara jumlah penduduk miskin yang terendah di Kota Dumai mencapai 13,76 di tahun 2016. Kemiskinan di Indonesia khususnya di Provinsi Riau memiliki karakteristik spesifik mengikuti keberagaman tipologi geografis, suku, dan adat masyarakat setempat. Masalah kemiskinan masih menjadi salah satu persoalan mendasar yang menjadi pusat perhatian pemerintah di manapun, termasuk di Kabupaten Indragiri Hilir.

Kabupaten Indragiri Hilir merupakan salah satu sentra produksi kelapa di Indonesia dan sebagian besar peduduknya berusaha di sektor kelapa sebagai mata pencaharian utamanya. Disisi lain, kabupaten ini memiliki persentase penduduk miskin yang tinggi diantara kabupaten/kota yang ada di Provinsi Riau. Indragiri Hilir, dengan julukan Negeri Hamparan Kelapa Dunia. Menurut Dinas Perkebunan Kabupaten Inhil perkebunan kelapa yang ada di Inhil terluas di dunia dan 80 persennya adalah milik masyarakat setempat mencapai 431.000 hektare. Perkebunan kelapa sejalan dengan kultur masyarakat pesisir dan penyebaran penduduk di sepanjang sungai Indragiri. Kelapa di Kabupaten Indragiri Hilir telah turun temurun menjadi komoditas utama, penopang perekonomian rakyat. Komoditas tersebut telah mengkhususkan Kabupaten Indragiri Hilir sebagai daerah kluster produksi kelapa serta kabupaten penghasil kelapa terbesar di Indonesia. Kelapa di Kabupaten 
Indragiri Hilir memang menjadi daya tarik utama investor, akan tetapi masih terdapat kendala dalam hal sumber daya manusia pada pengelolaan kelapa. Akibatnya, kelapa dirasa belum memberikan manfaat yang maksimal bagi masyarakat Indragiri Hilir. Selain itu mengembangkan komoditas perkebunan, Kabupaten Indragiri Hilir juga mengembangkan industri perikanan dengan melakukan budi daya terhadap kepiting dan udang.

Jumlah penduduk dengan kesejahteraan rendah di Kabupaten Indragiri Hilir (Inhil), Riau pada tahun 2016 meningkat signifikan sebesar 163.092 jiwa dari total penduduk tahun 2016 sebanyak 612.665 jiwa. Data Badan Pusat Statistik (BPS), jumlah persentase penduduk miskin atau sangat miskin di Kabupaten Inhil pada tahun 2015 lalu mencapai 56.850 jiwa atau sekitar 8,10\%. Jumlah ini meningkat dibandingkan tahun 2014 yang hanya mencapai 7,51\%. Masalah kemiskinan masih menjadi salah satu persoalan mendasar yang menjadi pusat perhatian pemerintah Kabupaten Inhil, apalagi Inhil merupakan salah satu kabupaten dengan jumlah penduduk miskin di Provinsi Riau.

Persoalan listrik yang selalu hidup mati di Kabupaten Indragiri Hilir hingga saat ini seperti tidak ada solusi. Masyarakat tidak bisa menikmati listrik secara utuh. Beberapa kawasan di Kabupaten Indragiri Hilir masih banyak yang merupakan daerah tertinggal. Listrik belum masuk dan jalanan masih banyak yang belum diaspal. Sebanyak 210 desa yang belum menikmati aliran listrik. Krisis listrik berlarut-larut dan masyarakat belum bisa mendapatkan pasokan listrik yang memadai yang sudah berlangsung cukup lama. Masyarakat di desa harus rela bermalam tanpa energi listrik, dan hanya beberapa saja yang mampu menerangi huniannya dengan perangkat seperti genset. Kalaupun ada genset, hanya sebatas menerangi rumah. Untuk televisi, beberapa desa hanya TVRI yang dapat terjangkau kalaupun ada siaran yang lain itupun sulit didapat. Beberapa desa di Kabupaten Indargiri Hilir desa terisolir yang berada di wilayah pedalaman. Untuk menjangkau desa tersebut, dibutuhkan waktu lebih dua jam dengan menggunakan jalur perairan dari Kota Tembilahan yang merupakan Ibu Kota Indragiri Hilir.

Prasarana kesehatan puskesmas, rumah sakit sudah dapat ditemukan karena sudah tersebar di kota-kota, sedangkan di desa-desa fasilitas kesehatan sulit ditemukan karena pengadaan tempat-tempat kesehatan belum merata. Fasilitas kesehatan belum mampu menyediakan satu desa satu dokter, setidaknya ada rumah sakit terdekat yang mampu mengakomodir beberapa desa terdekat. Bahkan untuk mencapai kota di butuhkan waktu dua jam dengan menggunakan transportasi laut.

\section{METODE PENELITIAN}

Metode yang digunakan dengan pendekatan kuantitatif yang bertujuan untuk memperoleh gambaran secara menyeluruh mengenai kemiskinan. Untuk memperoleh data sekunder yang diperlukan dalam penelitian ini adalah data Podes tahun 2003, 2006, 2008, 2011 dan 2014 yang dilakukan di Kabupaten Indragiri Hilir. Sampel di gunakan berjumlah 465 desa di Kabupaten Indragiri Hilir. Teknik analisis yang digunakan regresi data panel.

Metode estimasi model regresi dengan menggunakan data panel dapat dilakukan melalui tiga pendekatan, antara lain:

1. Model Pooled Least Square (Common Effect)

Model pendekatan di kenal dengan estimasi Common Effect yaitu teknik regresi yang paling sederhana dengan cara mengkombinasikan data cross section dan time series, model ini tanpa memperhatikan perbedaan waktu maupun individu, dengan persamaan regresi sebagai berikut:

$$
Y_{i t}=\beta_{0}+\beta_{1} X_{i t}+\beta_{2 i t}+\ldots .+\beta_{p} X_{p i t}+\mu_{i t}
$$




\section{Model Fixed Effect}

Model pendekatan Fixed Effect ini menggunakan variabel Dummy yang dikenal dengan model efek tetap atau least square dummy variabel. Pada metode fixed effect estimasi dapat dilakukan dengan tanpa pembobotan (no weight) atau least square dummy variable (LSDV) serta dengan pembobotan (crosssection weight) atau general least square (GLS). Dapat ditulis rumus sebagai berikut:

$$
Y i t=\beta_{0}+\beta_{1} X_{i t}+\beta_{2} W_{1 i t}+D_{2} Z_{1 i t}+\varepsilon_{i t}
$$

\section{Model Random Effect}

Dalam penggunaan model random efek, parameter yang berbeda diakomodasi pada error term pada masing-masing lintas unit dikarenakan berubahnya waktu dan berbedanya observasi, karena hal inilah model ini disebut juga komponen error (Error Component Model) Dapat ditulis rumus sebagai berikut:

$$
Y_{i t}=\beta_{0}+\beta_{1} X_{1 i t}+\beta_{2} X_{2 i t}+\ldots+\beta_{p} X_{p i t}+\varepsilon i t+\mu_{i t}
$$

\section{Pemilihan Model}

Untuk memilih model yang paling tepat digunakan dalam mengolah data panel, terdapat beberapa pengujian yang dapat dilakukan yakni:

1. Uji Chow

Chow test yakni pengujian untuk menentukan model Fixed Effect atau Random Effect yakni paling tepat digunakan dalam mengestimasi data panel. (Widarjono,2007)

2. Uji Hausman

Hausman test adalah adalah pengujian statistic untuk memilih apakah model Fixed Effect atau Random Effect yang paling tepat digunakan (Basuki, 2014).

3. Uji Lagrange Multiplier

Untuk mengetaui apakah model Random Effect lebih baik daripada metode Common Effect (OLS) digunakan uji Langrange Multiplier (LM). (Gujarati, 2012)

\section{Uji Asumsi}

\section{Uji Multikolinearitas}

Multikolinearitas dapat diartikan sebagai suatu keadaan dimana satu atau lebih variabel bebas dapat dinyatakan sebagai kombinasi kolinier dari variabel yang lainnya. Uji ini bertujuan untuk mengetahui apakah dalam regresi ini ditemukan adanya korelasi antar variabel independen.

2. Uji Heteroskedastisitas

Suatu model regresi dikatakan terkena heteroskedastisitas apabila terjadi ketidaksamaan varaians dari residual dari suatu pengamatan ke pengamatan yang lain. Jika varians dari residual dan satu pengamatan ke pengamatan yang lain tetap, maka di sebut homoskedastisitas. Jika varians berbeda di sebut heteroskedastisitas.

\section{Model}

Persamaan model dengan menggunakan data cross section dapat ditulis sebagai berikut:

$$
Y i=\beta_{0}+\beta_{1}+X_{i}+\mu_{i} ; i=1,2, \ldots, N
$$

dimana $\mathrm{N}$ adalah banyaknya data cross section, sedangkan persamaan model dengan time series adalah:

$$
Y t=\beta_{0}+\beta_{1}+X_{t}+\mu_{t} ; t=1,2, \ldots, T
$$


dimana T adalah banyaknya data time-series. Dengan menggabungkan data time series dan cross section, panel menyediakan panel data yang lebih banyak dan informatif yang lebih lengkap serta bervariasi. (Baltagi, 2005) maka model dapat ditulis dengan:

$$
\begin{aligned}
& \text { Yit }=\beta_{0}+\beta_{1}+X_{i t}+\mu_{i t} \\
& K=\beta 0+\beta_{1} P_{i}+\beta_{2} J_{S R S}+\beta_{3} P_{T V R I}+\beta_{4} S M_{i}+\beta_{5} S T_{i}+\beta_{6} J_{R S} S_{i}+\beta_{7} A R S_{i}+e
\end{aligned}
$$

Yang mana:

$$
\begin{array}{ll}
\mathrm{K} & =\text { Kemiskinan } \\
\beta 0 & =\text { Konstanta } \\
\beta_{1} \mathrm{PL}_{\mathrm{i}} & =\text { Pengguna listrik } \\
\beta_{2} \mathrm{JSRS}_{\mathrm{i}} & =\text { Jumlah sarana rumah sakit } \\
\beta_{3} \mathrm{PTVRI}_{\mathrm{i}} & =\text { Pengguna TVRI } \\
\beta_{4} \mathrm{SM}_{\mathrm{i}} & =\text { Sungai untuk melintas } \\
\beta_{5} \mathrm{ST}_{\mathrm{i}} & =\text { Sungai untuk transportasi } \\
\mathrm{B}_{6} \mathrm{JRS}_{\mathrm{i}} & =\text { Jarak RS ke desa } \\
\beta_{7} \mathrm{ARS}_{\mathrm{i}} & =\text { Akses rumah sakit }
\end{array}
$$

\section{HASIL DAN PEMBAHASAN}

Pemilihan Metode Estimasi

Pemodelan dalam menggunakan teknik regresi panel data dapat dilakukan dengan menggunakan tiga pendekatan alternatif metode dalam pengelolahannya. Pendekatan-pendekatan tersebut adalah Metode Common Constant (The Pooled OLS Method). Metode Fixed Effect dan yang terakhir adalah Metode Random Effect. Dalam memilih satu diantara ketiga metode tersebut, ada tiga tes yang digunakan, yaitu Chow Test, The Breusch Pagan LM Test dan Hausman Spesification Test.

1. Restricted F- test (Chow Test)

Restricted F-test (Chow Test) digunakan untuk mengetahui apakah lebih baik tepat menggunakan model Pooled Least Square atau Fixed Effect menunjukkan nilai probabilitas (Prob>F) 0,0000. Bahwa hasil uji Chow chi-square sebesar 0,0004 lebih kecil dari 0,05 maka penggunaan model lebih baik Fixed Effect dibandingkan model regresi Pooled Least Square

2. Breusch-Pagan LM Test

Breusch-Pagan LM test digunakan untuk mengetahui apakah lebih baik tepat menggunakan model Pooled Least Square atau Random Effect. Uji Breusch-Pagan LM test menunjukkan nilai (Prob>chi2) 0,0000. Dari hasil besarnya nilai Prob>chibar2 $=1.0000$ berarti penggunaan model lebih baik Pooled Least Square dibandingkan model regresi Random Effect

3. Hausman Test

Hausman Test dilakukan untuk menentukan apakah lebih tepat menggunakan model Random Effect atau Fixed Effect. Berdasarkan diperoleh hasil pemilihan model regresi Fixed Effect lebih baik dibandingkan model regresi Random Effect.

Kesimpulan yang diambil dari ketiga uji ini adalah baik model pertama, kedua, dan ketiga menggunakan metode regresi Fixed Effect. 


\section{Asumsi Klasik}

1. Multikolinearitas

Setelah dinyatakan data berdistribusi normal, pengujian selanjutnya adalah uji asumsi multikolinearitas dari hasil pengujian nilai korelasi $<0,75$ yang berarti tidak terdapat multikolinearitas dari masing-masing variabel.

2. Heteroskedastisitas

Untuk mengetahui ada tidaknya heteroskedastisitas masyarakat digunakan Breusch-Pagan / Cook-Weisberg test. Hasil pengujian menunjukan tidak adanya masalah heteroskedastisitas, dimana nilai (Prob>Chi2) kurang dari alpa $(0,05)$.

Tabel 3. Robustness Test

\begin{tabular}{|c|c|c|c|}
\hline Variabel & $\begin{array}{c}(1) \\
\text { OLS Model }\end{array}$ & $\begin{array}{c}(2) \\
\text { Fixed Effect Model }\end{array}$ & $\begin{array}{c}\text { (3) } \\
\text { Random Effect Model }\end{array}$ \\
\hline Pengguna listrik & $\begin{array}{l}-10.544 \\
(0,220)\end{array}$ & $\begin{array}{c}1.723 \\
(0,902)\end{array}$ & $\begin{array}{c}-10.544^{*} \\
(0,188)\end{array}$ \\
\hline Jumlah sarana rumah sakit & $\begin{array}{c}-68.295^{\star \star} \\
(0,006)\end{array}$ & $\begin{array}{c}-58.014^{\star \star *} \\
(0,000)\end{array}$ & $\begin{array}{c}-68.295^{\star *} \\
(0,007)\end{array}$ \\
\hline Pengguna TVRI & $\begin{array}{c}-20.033^{* *} \\
(0,081)\end{array}$ & $\begin{array}{c}-29.478^{* *} \\
(0,036)\end{array}$ & $\begin{array}{c}-20.033^{\star *} \\
(0,074)\end{array}$ \\
\hline Sungai untuk melintas & $\begin{array}{l}13.500 \\
(0,300)\end{array}$ & $\begin{array}{l}26.820 \\
(0,648)\end{array}$ & $\begin{array}{l}13.500 \\
(0,310)\end{array}$ \\
\hline Sungai untuk transportasi & $\begin{array}{c}6.749 \\
(0,486)\end{array}$ & $\begin{array}{l}24.002 \\
(0,178)\end{array}$ & $\begin{array}{c}6.749 \\
(0,488)\end{array}$ \\
\hline Jarak rumah sakit ke desa & $\begin{array}{r}-0.741^{* * *} \\
(0,000)\end{array}$ & $\begin{array}{c}-0.572^{* * *} \\
(0.001)\end{array}$ & $\begin{array}{c}-0.741^{* * *} \\
(0.001)\end{array}$ \\
\hline Akses rumah sakit & $\begin{array}{l}-16.724^{* *} \\
(0,003)\end{array}$ & $\begin{array}{c}3.038 \\
(0.750)\end{array}$ & $\begin{array}{c}-16.724^{* *} \\
(0.003)\end{array}$ \\
\hline Constanta & $\begin{array}{c}136.623^{* * *} \\
(0.000)\end{array}$ & $\begin{array}{l}46.456 \\
(0.449)\end{array}$ & $\begin{array}{c}136.623^{* * *} \\
(0.000)\end{array}$ \\
\hline$R$-squared & 0,056 & 0,042 & 0,029 \\
\hline Number of obs & 465 & 465 & 465 \\
\hline
\end{tabular}

Robust Standart Errors In Parentheses ${ }^{* * *} p<0,01,{ }^{* *} p<0,05,{ }^{*} p<0,10$

Variabel pengguna listrik memiliki arah negatif, yang menandakan bahwa semakin banyak pengguna listrik maka kemiskinan akan menurun. Hal tersebut sesuai dengan studi yang dilakukan oleh Straub dan Terada (2010) infrastruktur listrik memiliki pengaruh signifikan mengurangi kemiskinan. Variabel jumlah sarana rumah sakit berpengaruh negatif signifikan, semakin banyak jumlah sarana rumah sakit, maka kemiskinan akan menurun. Studi yang sama yang dilakukan Raihan (2011) di Bangladesh dan Granados di Meksiko menekan pentingnya infrastruktur secara 
umum mengurangi kemiskinan. Variabel pengguna TVRI memiliki arah negatif, yang menandakan bahwa semakin banyak TVRI maka kemiskinan akan mengurangi kemiskinan. Hal yang sama dikemukakan oleh Ahmed (2013) bahwa memperkenalkan teknologi baru dan informasi menjadi lebih mudah digunakan untuk memberdayakan masyarakat dan meningkatkan hidup. Teknologi akan mengurangi kemiskinan. Variabel akses rumah sakit memiliki arah negatif signifikan yang menandakan bahwa semakin mudah akses ke puskesmas maka kemiskinan akan semakin menurun. Studi yang sama di kemukakan oleh Oraboune (2008) bahwa hubungan signifikan antara akses sarana kesehatan dengan desa untuk mengurangi biaya transportasi.

Variabel sungai untuk melintas memiliki arah positif dan tidak signifikan yang menandakan bahwa semakin banyak sungai melintas maka kemiskinan akan semakin meningkat. Variabel sungai untuk transportasi memiliki arah positif, yang menandakan bahwa semakin banyak sungai untuk transportasi maka kemiskinan akan semakin meningkat. Sungai sebagai jalur transportasi utama masyarakat Riau. Riau merupakan daerah maritim yang terpisah dari laut selat dan sungai hal ini menjadikan masyarakat yang tinggal di daerah pesisir seperti Kabupaten Indragiri Hilir.

\section{SIMPULAN}

Variabel pengguna listrik, pengguna TVRI, Jarak rumah sakit ke desa dan akses rumah sakit mempunyai nilai negatif dan signifikan, yang menandakan semakin banyak masyarakat menggunakan listrik, TVRI dan akses rumah sakit maka akan mengurangi kemiskinan. Variabel jarak ke rumah sakit menandakan bahwa semakin dekat jarak desa ke rumah sakit maka berkurangnya tingkat kemiskinan. Sedangkan variabel sungai untuk melintas antar desa dan sungai untuk transportasi mempunyai nilai positif dan tidak signifikan, yang menandakan bahwa semakin banyak sungai untuk transportasi maka kemiskinan akan semakin meningkat. Kabupaten Indragiri Hilir adalah wilayah perairan yang memiliki 12 sungai besar. Disamping sungai-sungai tersebut masih terdapat kanal yang dijadikan sebagai sarana prasarana perhubungan masyarakat maka dari kondisi tersebut daerah ini dijuluki Negeri Seribu Parit. Jalur utama transportasi perairan antara satu desa ke desa lainnya, atau menuju ke kota-kota yang lebih besar. Beberapa sungai merupakan jalur utama transportasi perairan antara satu desa ke desa lainnya, atau menuju ke kota-kota yang lebih besar. Sungai merupakan alat urat nadi perekonomian masyarakat sebagai prasarana transportasi dan kehidupan bagi daerah yang dilintasinya. Bagi desa-desa yang tidak terjangkau jaringan listrik PLN, maka dapat diupayakan kebutuhan listriknya dari PLTD yang dikelola bersama Pemerintah Desa bersama pihak lainnya. Karena kebutuhan listrik ini sangat penting bagi masyarakat, seperti untuk pendidikan dan industri lainnya yang memerlukan pasokan listrik, terutama di malam hari. Memperbaiki dan membangun jalan yang rusak sehingga masyarakat tidak selalu menggunakan transportasi sungai sebagai sarana jalan.

\section{REFERENSI}

Ahmed, Allam. (2013). Technological Readiness in the United Arab, Emirates, Towards Global Competitiveness. World Journal of Enterpreneurship, Management and Sustainable Development, Vol.9 Issue, 1.

Badan Pusat Statistik Riau. (2017). Riau Dalam Angka.Pekanbaru. Riau.

Basuki, Agus \& Imamudin. (2014). Elektronik Data Prosesing (SPSS 15 dan. EVIEWS 7), Yogyakarta. 
Chalid, Nursiah \& Yusuf Yusbar. (2014). Pengaruh Tingkat Kemiskinan, Tingkat Pengangguran, Upah Minimum Kab/Kota dan Laju Pertumbuhan Ekonomi Terhadap ndeks Pembangunan Manusia di Propinsi Riau. Jurnal Ekonomi, Vol.22, No. 2.

Chatterjee, Santanu, Morshed, AKM, Mahbub. (2011). Intrastructure Provision and Macroeconomic Peformance.

Damodar N Gujarati. (2012). Ekonometrika Dasar. Jakarta: Penerbit Erlangga.

Maryanti, Sri. (2009). Analisia Pertumbuhan Ekonomi dan Tingkat Kemiskinan di Propinsi Riau. Pekbis Jurnal, Vol.1, No.3.

Oraboune, Syviengxay. (2008). Infrastructure Development in Lao PDR, Institute of Developing Economies Netro, Japan.

Raihan, Selim, Noyolitzin, Nayeli. (2015). Does Transportation Infrastructure Reduce Poverty? Evidence From the Free Federal Trunk Highway System in Mexico.

Santanu, Chatterjee, Morshed, AKM Mahbub. (2011). Instructure Provision and Macroeconomics Performance.

Setboonsarng, Sununtar. (2005).Transport Infrastructure and Poverty Reduction. ADBI Research Policy Brief, No 21

Straub, Stephane, Terada, Hagiwara, Akiko. (2010). Infrastructure and Growth in Developing Asia. Asian Developing Bank Economic Working Paper Series, No. 231.

Taruna Shalini Ramessur, Seetanah Boopen \& Swakut Rojid. (2009). Urban Infrastructure and Poverty Alleviation in Africa. The World Bank, Policy Research Working Paper, 1252.

Wang, Yanhui \& Baixue Wang. (2016). Multidimensional Poverty Measure and Analysis: A Case Study From Hechi City, China, Wang and Wang, Springer, Plus 2016.

Wang, Zhiyang, Sizhong Sun. (2016). Transportation Infrastructure and Rural Development in China. China Agricultural Economic Review, Vol. 8 Issue: 3.

Widarjono. A. (2007). Ekonometrika Teori dan Aplikasi. Yogyakarta: Ekonisia. FE UII. 